\title{
OPTIMALISASI ZISWAF UNTUK PEMBANGUNAN EKONOMI INDONESIA MELALUI SEKTOR KEUANGAN DIGITAL
}

Perkembangan teknologi yang semakin pesat membuat elemen masyarakat dituntut untuk dapat beradaptasi di zaman ini. Terlebih kondisi dan situasi pandemi membuat aktivitas masyarakat menjadi terbatas. Dua hal ini memberikan dampak yang signifikan yakni, ekonomi, sosial budaya, dan pendidikan. Dari segi kebutuhan umat pun tak lepas dari peran teknologi, baik dari kebutuhan berskala mikro hingga kebutuhan negara. Airlangga Hartanto yakni MENTERI Koordinator Bidang Perekonomian menaksir bahwa selama pandemi membuat transformasi perilaku masyarakat yang menjadikan peluang bagi sektor keuangan digital. Perubahan ini juga lebih mendukung ke arah pemanfaatan Financial Technology maupun sektor perbankan yang berimplikasi pada pemanfaatan dan pemberdayaan ZISWAF.

Statistik penghimpunan Zakat, infak, dan sedekah (ZIS) tahun 2020 mengalami eskalasi sebesar 30 persen dari tahun 2019. Sepanjang 2020, BAZNAS telah menghimpun dana sebanyak Rp385,5 Miliar yang mana pada tahun sebelumnya penghimpunan mencapai Rp296 Miliar. Tak hanya demikian, Pernyataan Ketua Baznas, Noor Ahmad yang dilansir dari CNBC Media memprediksi sebanyak Rp327 Triliun zakat dan wakaf sebanyak Rp187 Triliun sehingga mengenai potensi ZISWAF di Indonesia dapat memenuhi angka Rp500 Triliun bahkan lebih. Artinya Indonesia harusnya dapat memanfaatkan potensi tersebut sebagai pertumbuhan serta pembangunan ekonomi yang signifikan.

Beragam platform digital dapat menjadi bagian dari solusi dari sektor keuangan untuk pengoptimalan ZISWAF. Salah satu platform yang bergerak adalah E-Commerce yang mengalami kenaikkan tiga sampai lima kali lipat di tengah kondisi pandemi.

Adapun peran platform dalam Fintech Syariah yang telah terdaftar di OJK yang menerapkan sistem crowdfunding juga dapat mengoptimalkan ZISWAF melaui konsep 
tersebut. Seperti salah satu platform ternama yakni OVO yang telah berkolaborasi dengan beragam platform mitra ZISWAF seperti BAZNAS, Dompet Dhuafa, Kitabisa, LAZ Al-Azhar, We Care id, NU Care LazisNU, Rumah Yatim, Rumah Zakat, Yayasan Anyo Indonesia, Yayasan Cinta Anak Bangsa, BenihBaik, dan Yayasan Tangan Harapan

Selain itu, institusi seperti KNEKS juga ikut berandil dalam optimalisasi tersebut. Melalui platform yang sedang dibentuk KNEKS yaitu zakat dan wakaf berbasis kewilayahan guna akan menghasilkan zakat nasional dalam satu database. Direktur Eksekutif Manajemen Ekskutif KNEKS, Ventje Rahardjo mengujar bahwa harapan itu bisa menjadi satu platform, antara platform zakat, wakaf, dan masjid dapat berkolaborasi dengan platform dalam fintech syariah.

Institusi lainnya yakni BSI juga terus menggencar pengumpulan dan penyaluran ZISWAF. Dengan penyaluran ZISWAF secara instan melalui platform BSI Mobile dapat membuat BSI juga menjadi pilihan masyarakat. Terdapat kisaran Rp3,26 miliar dana yang telah dihimpun melalui aplikasi BSI Mobile per-maret 2021 lalu. Total transaksi mencapai 303.000 yang berasal dari 99.000 donatur pada periode tersebut. Agar terwujudnya kemudahan akses informasi data zakat antara kedua institusi, BSI pun telah melakukan kolaborasi dengan BAZNAS dengan sistem yang berjalan, yaitu penggunaan kartu CoBrand Tap Cash IB Hasanah dengan pembinaan manajemen mitra penghimpunan Baznas.

Keberadaan beberapa platform resmi menjadi mudah digunakan masyarakat untuk berdonasi dengan hanya mengklik aplikasi tanpa harus secara langsung ke tempat lembaga filantropi. Inilah yang harus dimanfaatkan masyarakat agar optimalisasi pembangunan ekonomi di Indonesia semakin berjalan dengan baik. Tentunya didorong dengan literasi masyarakat terhadap keuangan syariah dan juga penggunaan platoform yang telah memperoleh legalitas pemerintah sehingga adanya transparansi data-data yang diperoleh negara. 


\section{Daftar Pustaka}

KNEKS. 2020, Gerakan Platform Digital Maksimalkan Donasi Masyarakat. https://knks.go.id/berita/244/gerakan-platform-digital-maksimalkan-donasimasyarakat?category=1, diakses pada tanggal 20 Oktober 2021.

Keuangan.kontan. 2021, Bank Syariah Indonesia (BSI) ambil peran dalam optimalisasi Ziswaf di Indonesia. https://keuangan.kontan.co.id/news/bank-syariah-indonesia-bsiambil-peran-dalam-optimalisasi-ziswaf-di-indonesia, diakses pada tanggal 20 Oktober 2021.

KNEKS. 2020, Fintech Tak Bisa Dipisahkan dari Ekosistem Ekonomi Syariah. https://knks.go.id/berita/330/fintech-tak-bisa-dipisahkan-dari-ekosistem-ekonomisyariah?category=1, diakses pada tanggal 20 Oktober 2021.

CNBC INDONESIA. 2021, Baznas: Potensi Ziswaf RI Lebih dari Rp 500 Triliun. https://www.cnbcindonesia.com/news/20210503115816-4-242645/baznas-potensiziswaf-ri-lebih-dari-rp-500-triliun, diakses pada tanggal 20 Oktober 2021.

BAZNAS. 2021, Masa Pandemi 2020, Penghimpunan BAZNAS Naik 30 Persen. https://baznas.go.id/Press_Release/baca/Masa_Pandemi_2020,_Penghimpunan_BAZN AS_Naik_30_Persen/689, diakses pada tanggal 20 Oktober 2021.

REPUBLIKA. 2021, OVO Ajak Masyarakat Donasi Digital Melalui Mitra ZISWAF. https://www.republika.co.id/berita/qwp2so349/ovo-ajak-masyarakat-donasi-digitalmelalui-mitra-ziswaf, diakses pada tanggal 20 Oktober 2021. 